\title{
Mental freedom: Who has control-the rider or the horse?
}

\author{
Jane $L$ Wiesner
}

\section{Correspondence:}

janew@profres.com.au

Humanities and Social Sciences,

Faculty of Arts and Education,

Deakin University, Burwood

Highway, Burwood, Victoria 3125,

Australia

\section{Springer}

\begin{abstract}
Background: This paper has been reproduced and modified from a PhD dissertation (Deakin University, 2013) written by the author titled 'Freedom and Conditionality: Analysing Mental and Yogic Models of Freedom'. It is a cross-cultural, crossdisciplined work based on an exploration into Eastern and Western concepts of mental freedom.

Methods: The thesis methodology included a critical analysis and examination of various theories relating to emotional life. To achieve this aim textual exploration and empirical research was carried out. The empirical data collected included questionnaires and interviews pertaining to life-experiences in terms of emotional well-being, which is discussed in context as "mental freedom").

Results and Discussion: This paper is taken from the results of the research, in particular Chapter Five of the thesis, which will be published early next year by Cambridge Scholars Publishing under the title 'Freedom Beyond Conditioning: East West'. The paper discusses key elements related to emotional well-being in particular Sigmund Freud's philosophical approach to certain aspects of his theories, including the life and death instinct and the organisation of the personality. The paper also introduces key Eastern theories in respect to Yogic traditions, which it relates to Freud's id, ego and superego and theory of dynamic (psychical) energy.

Conclusions: The paper concludes that certain elements of Freud's theories and Eastern philosophy share important parallels that relate to the individual's ability or inability to achieve mental freedom.

Keywords: Kleșas; Ignorance (avidyā); I-am-ness (asmitā); Attachment (räga); Aversion (dveșa); Clinging-to-life or fear (abhiniveśa); Desire; Freud; Taimni; Yoga; Psychoanalysis; Mental freedom; Conditionality; Id; Ego; Superego; Pleasure and pain
\end{abstract}

\section{The reins of the ego and the id}

Austrian psychoanalyst Sigmund Freud may well have known more about Eastern philosophy than scholarly opinion suggests. His insight into the human mind has certain parallels to Yogic theory. Like Freud, Yogic theorists explore the tug of war that explodes between the conscious and the unconscious minds when reason falls victim to desire. Freud claims that with conscious awareness the ego ${ }^{\text {a }}$ works towards resolution and mediation, whereas the hungry id ${ }^{\mathrm{b}}$ strives to fulfill all wishes with unbridled urgency. To explain this further he uses the analogy of a rider and a horse:

(c) 2014 Wiesner; licensee Springer. This is an Open Access article distributed under the terms of the Creative Commons Attribution License (http://creativecommons.org/licenses/by/4.0), which permits unrestricted use, distribution, and reproduction in any medium, provided the original work is properly credited. 
One might compare the relations of the ego to the id with that between a rider and his horse. The horse provides the locomotive energy, and the rider has the prerogative of determining the goal and of guiding the movements of his powerful mount towards it. But all too often in the relations between the ego and the id we find a picture of the less ideal situation in which the rider is obliged to guide his horse in the direction in which it itself wants to go (Freud, 2008).

The id, like a powerful mount, surges forward towards the object of its desire. The goal of this paper is to examine the nature of this surging in contrast to particular aspects of Yogic theory. George Vaillant explains, in The Wisdom of the Ego, how Freud's analogy of the ego is connected to Plato's horseman-a horseman who precariously tries to ride two horses at once, Vaillant writes thus:

Goaded by the selfish impulses of the id, hemmed in by the moral constraints of the superego, rebuffed by reality, the ego struggles to cope and to reduce the forces that work on it to some kind of harmony. The ego institutes delay in our instinctual behaviour: Look before you leap (Vaillant, 1995, p. 7).

Both Plato and Freud's approach to the horseman's struggle suggests that the mind's makings are tightly woven threads that stretch between the desire for pleasure and the need to avoid pain. At the core of this thread is the object of desire. In Yogic terms this is known as the klesia, rāga, which is commonly described as attachment ${ }^{\mathrm{c}}$. There are five klesias described in Classical Yogic theory ${ }^{\mathrm{d}}$. It is important to note that the klesias are interconnected and therefore where one exists the others will follow. Klesas are said to be at the heart of emotional affliction. Klesias are unhelpful categories or aspects of emotional life that include avidyā (ignorance), asmitā (I-am-ness), rāga (desire, attachment), dveșa (aversion) and abhiniveśa (the will to live) (Feuerstein, 1989, p. 61). A more simplistic description might be unawareness, self-absorption, craving, hatred and fear.

$R \bar{a} g a$ is defined by noted Indologist I.K. Taimni as 'the attraction one feels towards any person, or object, when any kind of pleasure or happiness is derived from the person or object' (Taimni, 1979, p. 147) ${ }^{\mathrm{e}}$. Yogic theory suggests that one seeks pleasure or gratification from the external world because it is difficult to source this satisfaction internally: the veil of ignorance overrides one's ability to feel the joy (ānanda) inherent to human nature. Taimni likens the klesias to a tree, where the five klesias represent the roots, trunk, branches, leaves and fruit. This integrative approach to the more unhelpful attributes of human emotion demonstrates the dependency one klesia has towards the other. Therefore, when considering rāga in the kleśa tree, one is compelled to stress how intrinsically related it is to the other kleśas. For instance, rāga is simply the flip side of dveșa (aversion): what one loves is contrasted by what one hates. One could argue that hatred is the result of fear, a fear borne from an emotional or physical disconnection from "the other". Irrational or unwarranted fears have roots in ignorance, as the heart of fear is the threat of the unknown, misconceived or misunderstood. As Taimni's metaphor suggests rāga branches out in attachment, creating a bridge between the wantings of the self-identity and the repulsions that contrast it: pleasure and pain. The concept of pleasure and pain as a driving force for the human is condition is not foreign to academic debate. Freud's theories of the unconscious address the dichotomy 
of pleasure and pain ${ }^{\mathrm{f}}$. Where Freud analyses, Yoga transcends: both striving for a degree of liberation from the binding effects of pleasure and pain.

Freud's theories were controversial at the time, and to this day they are often debated. Some say he was a natural scientist. Others say that his approach was hermeneuticalthat it all had to do with meaning-that he wrote in metaphors and that science was simply a mask. I recognise these different interpretations and acknowledge that my view is just one approach. I concentrate on Freud's theory of psychic energy: inner forces and their influence on human life. Freud's concepts are particularly significant to my research because his philosophical and scientific analysis reveals much about the makings and psychical associations of the human mind-the freedom or bondage imposed by its unconscious workings.

According to Freud, human beings are 'more comfortable living with delusions and superstitions than with the truth' (Hall, 1979, p. 20). Freud recognises the cyclic nature of thinking, 'the influence of society, on man and man on society', that passes from generation to generation: one that often defies logic and reason (Freud, 2002, p. 58-63). His work follows a process of evolution as he constantly re-evaluates his own conclusions. This is demonstrated by his theory of the libido, which began as a purely psychical sexual energy and was later extended to the life and death instincts (Freud, 1975, p. 24). When discussing the mental life of a child Freud states in The future of illusion:

The libido follows the paths of narcissistic needs and attaches itself to the objects which ensure the satisfaction of those needs. In this way the mother, who satisfies the child's hunger, becomes its first love-object and certainly also its first protection against all the undefined dangers which threaten it in the external world-its first protection against anxiety, we may say (Freud, 1975, p. 24).

For Freud, this desire for protection has a major controlling influence in the growing child's life (a concept that recognises fear as the major source of anxiety). Eventually, the mother may be replaced by the father and this need for a 'father figure' is something Freud identifies as the underlying foundation of religious belief (Freud, 1975, p.24).

The need for protection is based on fear of a perceived threat, and the perception of an unfounded fear is undoubtedly a great challenge to freedom because it distorts one's conceptual awareness. Fear serves an obvious and necessary function- it prompts a person to avoid danger. However, the fear Freud recognises here is what remains unconscious (often

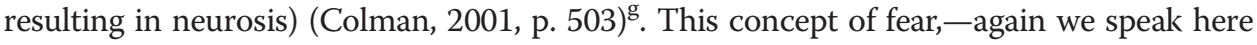
in terms of the fear of pain or of not having the object of one's desire-is paramount to both Eastern and Western philosophy, it is something Freud relates to drives ${ }^{\mathrm{h}}$.

Freud's analysis of the human personality reveals a great deal about the barriers to mental freedom. His work establishes a methodology or approach aimed at defusing controlling influences by providing an insight into the surreptitious nature of the unconscious mind. Freud, claims that 'psychical freedom' is not realistic, for without one's knowledge the unconscious mind continues to manifest itself even in the most innocent ways, for example by parapraxes (slips of the tongue) (Freud, 1991, p. 76). Although not explicitly using the term 'mental freedom', Freud provides a method of understanding the governing forces of the unconscious world. He derives his notion of 
the 'unconscious from the theory of repression'-forces that oppose conscious recognition-he describes what is repressed in terms of resistance (Freud, 2003, p. 206). The opposite end of this spectrum is being consciously aware.

To Freud, 'consciousness constitutes the outer surface of the psychic apparatus' (Freud, 2003, p. 110). In other words, it is a part of the psyche-system that is closest to the external world. He characterises consciousness as 'the surface of perception': what one senses and feels (Freud, 2003, p. 110). Freud also refers to it as the 'thought processes', establishing a connection between thinking and feeling (Freud, 2003, p. 110). His theories indicate that the dynamics of these thought processes, and how they relate to the structure of the personality, influence emotional and psychological balance; or, in terms of this paper, mental freedom.

\section{Freud, dynamic energy and attachment}

A person is a complex being made up of a million individual smells, tastes, memories, and hopes. Listen for a few minutes to the voices that run through your mind. Every psyche is a private theatre filled with scenes and characters. Listen and you will hear your father, mother, brothers, sisters, children, lovers, friends, enemies, teachers, and heroes acting out their dramas on your stage. Hearing the multiple voices within yourself will remind you that you belong to a special clan. Your people still inhabit you (Keen \& Valley-Fox, 1989, p.2).

Freud highlights the inner conflict of the human condition. He seeks to identify a process of the mind that Yogic philosophy suggests is veiled in ignorance (Feuerstein, 1989, p. 62). Freud's psychical energy is an important aspect of my research because his theory recognises that the determining forces of the personality often remain unknown to the observer. The concept of observation is imperative to the structure of Yogic philosophy, particularly in relation to freedom or liberation (Feuerstein, 1997, p. 257). Individual observation implies a relationship between the individual's experiences of the world and the interpretive filters used to assimilate these experiences, something Freud's and Yoga's theories link to pleasure and pain. Georg Feuerstein suggests that the way to freedom is found in apperception: Yoga's process of apperception is a unique awareness, where one is able to break free of a conditioned cycle of thought-where the perceiver is aware of the act of perceiving, a process that allows one to direct the mind and, as a result, control emotion (Feuerstein, 1989, p. 73). Freud's theories led him to doubt the concept of mental freedom, yet his treatment worked to allow the individual to reveal and, in a way, understand their mental processes.

Psychologist Gustav Theodor Fechner's insights led Freud to question if the pleasure principle has dominion over the psyche. Fechner writes:

Insomuch as conscious impulses are always associated with pleasure and unpleasure, we may suppose that pleasure and unpleasure, too, are linked psycho-physically to conditions of stability and instability (Freud, 2003, p. 46).

In contrast to Fechner, Freud proposes that the pleasure principle purely 'exists as a strong tendency' (Freud, 2003, p. 47). In making this conclusion, Freud developed a 
conceptual model for the human personality, applying the laws of physics (Freud, 2003, p.110). In his first year at the University of Vienna, Freud received supervision by German physiologist Ernst Wilhelm von Brücke who, in collaboration with physicist Hermann von Helmholtz, formulated the first law of thermodynamics (the law of conservation of energy) (McEvoy and Zarate, 2006, p. 17). Freud's theory explains that all living organisms (energy systems) are governed by this principle, which claims that energy is not destroyed, but simply changes form (Freud, 2003, p. 110).

Freud proceeds to create a dynamic theory of psychology based on the distribution and disposal of psychic energy within the personality, this suggests that the ability to think with any degree of clarity or freedom relates to the formation of the personality and to the distribution of psychic energy within that personality. He uses the term "libido" to refer to this psychic energy: energy fuelled by thought processes and sexual urges, and as he later determined, the life and death drives (Freud \& Breuer, 2004, p. 65).

Freud argues that the mind has a fixed amount of this psychic energy: it cannot create or destroy this energy but only transfer it from one kind of function to another (Stevenson, 2003). According to Freud, an individual's personality is determined by the changes, balance and interaction of this psychic energy within the mind and imbalance in this energy cause neuroses. The id, or primary process, is the source of this psychic energy. This concept of energy distribution, amongst other things, connects Freud's view to Eastern philosophy.

The Yoga-Sütras teach that the body and the mind are dependent on the free flow of prāṇa for vitality and well-being (Blashki, 2007). Like Patañjali, Freud connects the health and well-being of the individual with dynamic distribution of energy within the body-mind system (Freud, 2003, p. 110). Freud stresses that perceptions come from without (sense perceptions) and within (sensations or feelings), ultimately, linking psychic energy-flow with the concept of pleasure and pain (Freud, 2003, p. 110). Freud explains thus:

Sensations of a pleasurable kind generate no pressures at all; unpleasureable sensations, on the other hand, exert pressure to an extreme degree. They press for change, for release, and because of this I believe that unpleasure entails an increase in energy-cathexis ${ }^{\mathrm{i}}$, [and] pleasure a decrease (Freud, 2003, pp. 134 \& 113).

From a Yogic perspective, this energy is radically influenced by the kleśas. Again, Taimni's analogy of the roots, trunk, branches, leaves and fruit of a tree suggest that the kleśas are fundamentally linked, each part a piece of the whole (Taimni, 1979, p. 139). According to Taimni, avidyā is at the heart of all of the kleśas; it is described as the rootcause of the other kleśas, which collectively are said to 'produce all the miseries of human life' (Taimni, 1979, p. 139). Taimni explains that ignorance is the cause of human misconception: suggesting a "we can only know what we know" approach (Taimni, 1979, p. 139). Taimni claims that kleśas can be potential or active, adding that and they have four states:
1) Dormant;
2) Attenuated;
3) Alternating;
4) An expanded condition (Taimni, 1979, pp. $152 \& 139)^{j}$. 
The "dormant" condition describes a kleśa presented in a latent form (its lack of expression converts its energy to potential) (Taimni, 1979, p. 139). "Attenuated" describes a kleśa existing in a "weak" condition, ready to be activated when the slightest stimulus is applied (Taimni, 1979, p. 139). An "alternating" condition describes a kleśa with the tendency for two opposing forces, for example, attraction and repulsion (both of which are based on attachment, for one is repulsed by the extreme opposition to what one desires) (Taimni, 1979, p. 139). An expanding condition describes a kleśa that is fully active, something Taimni equates to 'the waves on the surface of the sea in a storm' (Taimni, 1979, p. 139).

Conditioned thought is associated with the last two states: alternating and expanded. Conditionality is the Buddhist term for conditioned thought, i.e. 'conditional thoughts that arise from events that go on to condition further events' (Fenner, 1987, pp. 217-227) ${ }^{\mathrm{k}}$. An alternating state creates inner conflict and a strong sense of uncertainty. The individual may feel fine while things are going well, but erupt into a state of emotional turmoil when things start to deteriorate. A good example of an expanded condition is the anger demonstrated by road rage. Here, the individual is beyond reason and the kleśa is an allconsuming experience.

Yogic theory suggests that mental suffering is not based on what we know, but rather on what we do not know, or misconception-viparyaya (Feuerstein, 1997, p. 335). It is not always clear to the individual why they think the way they do. Hence, when one's thoughts result in unhappiness or emotional pain the cause is not always apparent. The unhelpful ideas one holds on to, ideas that produce destructive core beliefs, are the very things that keep the individual captive on an emotional level, because they interfere with clarity of "knowing".

This concept of "not knowing" links back to Freud's organisation of the personality. Freud claims that the energy system of the personality has three major systems-the id, the ego $^{\mathrm{m}}$ and the superego ${ }^{\mathrm{n}}$ (Freud, 1978a, p. 106, 115 \& 124) ${ }^{\mathrm{o}}$. These systems are made up of psychic energy, which is drawn from the body's innate and vital energy source ${ }^{\mathrm{p}}$. As previously explained, Freud's psychic energy cannot be destroyed: if it disappears from one part of the personality it must reappear somewhere else. Hence, the healthy distribution of this psychic energy is crucial to the individual's ability to be free of mental perturbation.

To Freud, who a person becomes, as an individual (and in context with this paper the degree of freedom one achieves), is a direct product of the distribution of energy within the organisation of the personality. A healthy and well-adjusted person achieves balance and harmony between the id, the ego and the superego, allowing the person to achieve equilibrium and to have productive dealings or transactions within their environment. In other words, an individual is subject to 'realistic anxiety' rather than 'neurotic anxiety' (Freud, 1991, pp. 441-446). These three systems work together cooperatively in a healthy individual. An imbalance in these energy systems ultimately leads to maladjustment and disharmony, or neurotic anxiety. Freud explains this concept of anxiety thus (Freud, 1991, p. 441):

Realistic anxiety strikes us as something very rational and intelligible...it is a reaction to the perception of an external danger - that is, of an injury, which is expected and foreseen. It is connected with the flight reflex and it may be regarded as a manifestation of the self-preservation instinct... The second form of anxiety...is bound psychically 
and attached to particular objects or situations. This is the anxiety of the extremely multifarious and often very strange 'phobias' (Freud, 1991, pp. 441-446).

The deflection of the libido (dynamic energy) from its usual employment is the cause of the latter form of anxiety. When the three systems of the personality work in harmony the individual is able to have satisfactory transactions/interactions with their environment. In contrast, when the individual is dissatisfied or frustrated with themselves and the world, their ability to think with freedom and clarity is substantially reduced. Similarly, in Yoga the mind-body system reflects the effect of anxiety, for example the result of abhiniveśa, in a restriction of the flow of prāna (Feuerstein, 1998, p. 179). With regard to the kleșas, this anxiety can be linked back to what is dormant ${ }^{\mathrm{q}}$. Both theories highlight the complex rollercoaster of pleasure and pain caused by craving and wanting (attachment) and the tension this produces in the bio-system.

\section{The attachments of the id and the ego-pleasure versus reality}

Instinctual cathexes seeking discharge,-that, in our view, is all that the id contains (Freud, 2008).

The id creates a discharge of quantities of (excitation) energy or tension that is released in the organism through stimulation by either internal or external means (Freud, 2003, p. 45) ${ }^{\mathrm{r}}$. According to Freud, the id fulfills the primordial principle of life-'the pleasure principle' (Freud, 2003, p. 45). The pleasure principle aims to rid the individual of tension. It represents the tendency found in all living organisms, when faced with external or internal disturbances, to relieve tension and return to homeostasis (balance with the system) (Tortora \& Derrickson, 2006, p. iv) ${ }^{\mathrm{s}}$. In The principles of anatomy and physiology, physiologists G. J. Tortora and B. H. Derrickson explain that homeostasis ${ }^{\mathrm{t}}$ is $^{\mathrm{s}}$ a 'state of relative stability of the body's internal environment' (Tortora \& Derrickson, 2006, p.1). Fechner refers to this state as 'the tendency to stability' (Freud, 2003, p. 47).

In Freud's words, 'these processes strive towards gaining pleasure; psychical activity draws back from any event which might arouse unpleasure' (Freud, 1995, pp. 301-302). He claims that there is 'a powerful tendency inherent in every living organism to restore a prior state' (Freud, 2003, p. 76), a state that the organism may have been compelled to relinquish because of problematic external forces. Freud refers to this tendency as 'a kind of organic elasticity' (Freud, 2003, p. 76). This need to restore status to a prior state explains the 'drives' behind the 'pleasure principle', in other words, the pleasure one seeks may not be pleasure in its truest sense, it may well be a return to what is "comfortable" to the psyche (Freud, 2003, p. 45).

Freud uses an analogy for the psyche's desire to reach a state of resolution (Freud, 2003, p. 97). He refers to Plato's classic story of human origin as told in Symposium (Freud, 2003, p. 97). In this tale, the world once contained androgynous beings, which were made up of double the parts of a single human (Freud, 2003, p. 97). As the story goes, Zeus decided to cut these beings in half creating a longing by each half for the other and, ultimately, the desire to return to one living thing, venturing the hypothesis that because this living matter was divided it longed to reunite by way of sexual drives. 
Freud also connects this theory to the ancient writings of the Upanishads (800 BCE), Indian chronicles that claim that the self fell 'into two parts' (Freud, 2003, p. 252) ${ }^{\mathrm{u}}$. This, along with Freud's conjecture regarding the relief of tension (anxiety), creates interesting parallels between the East and West. Yoga also emphasises a need for balance between the male and female energies in the body and mind, and like Freud's theory, Yoga's Hatha Yoga techniques aim to reduce tension in an organism through meditation, breath control and physical postures.

Freud's theories link one's psychological development to the degree of dissatisfaction or discomfort experienced when tension is not discharged. For instance, the baby's desire for food and the baby's inability to satisfy this desire is connected to the development of the id, which results from the frustration experienced, something Freud calls the primary process (Freud, 2003, pp. 74-75). Freud connects this process to perception. Accordingly, when the "perception system" is activated one takes stock of the environment through sight, sound, taste, touch, smell (Hall, 1979, p. 25). The "memory system" stores that information in the form of a memory image (Freud, 2003, pp. 75-75). One's perception system, what is experienced through the senses, creates a memory trace that represents the object of the experience as a memory image (Freud, 2003, pp. 75-75). This is similar to the Yogic view-where a memory imprint is something one reproduces from a past perception (Feuerstein, 1998, p. 72) . $^{\mathrm{v}}$.

Freud maintains that when there is a need for the discharge of tension-and there is not an immediate satisfaction-the primary process attempts to reduce or discharge the tension by what Freud refers to as an 'identity of perception' (Hall, 1979, p. 25). This means that the actual memory image and the perception are seen as one and the same thing. In other words, 'the id fails to distinguish between a subjective memory image and an objective perception of the real object', as in the case of a hungry baby sucking his thumb (Freud, 1995, pp. 301-302). Thus, the id identifies this memory image with a perception of the real object (the thumb substitutes for food) (Freud, 1995, pp. 301-302).

Freud also relates a need for satisfaction to the dream process. He writes: 'The study of dreams may be regarded as the most reliable approach route for those seeking to understand the deep-level processes of the psyche' (Freud, 2003, p. 51). The primary process is at work when one dreams (Freud, 1999, p. 307) ${ }^{\mathrm{w}}$. Dreams help to discharge the pressure that has built up through the day by a series of images that reduce the tension, allowing the reliving of memories and events in a way that creates gratification on a psychic level (Freud, 1999, p. 387) ${ }^{\mathrm{x}}$. Freud refers to this image of a tension-reducing object as a wish-fulfillment, and dreams, for example, are an attempt at wishfulfillments (Freud, 1999, p. 181). In other words, one may dream about the things that one wants to have or to experience, but this is not always obvious because the dreaming process uses symbols as a substitute for the original objects (Freud, 1999, p. 181).

The primary process does not always fulfill the direct need or desire for the object, in which case the primary process becomes illusionary; by fantasy it allows one to imagine the fulfillment of desire (Freud, 1999, p. 181). The secondary process, the formation of the ego, produces a sense of reality. Where the id is disorganised and impulsive and relates to basic instincts, the ego (which is formed from the id) is a kind of supervisor, working to oversee the id (Freud, 1999, p. 181). Also, the secondary process affords recognition between internal and external fantasies, allowing the developing child to 
distinguish between real and imagined objects. The secondary process also creates a distinction between two or more desired objects, creating a degree of calculation within the child's psyche and allowing for the deferment of satisfaction.

Because the id is actually driven by the need for satisfaction or instinctual needs (which relates to the pleasure principle) it is not governed by laws of morality or reason. In fact, the id has two possible ways of discharging tension; it can attempt to discharge tension by wish fulfillment or by action. Or alternatively, it can bow down to the influence of the ego, in which case, the energy is subdued rather than discharged immediately. It is the job of the ego, to find a way to resolve the tension without succumbing purely to 'innate drive impulses' (Freud, 2003, p. 48).

The id exists in the inner world of the individual - a primordial state of being - and it exists before one's experience of the external world (Freud, 2003, p. 8). The id relates to reflexes and instincts that are innate (Freud, 2003, p. 8). Undoubtedly, this was an influential component in Carl Jung's theory of the collective unconscious (Jung, 1961, p. 160$)^{y}$. One could regard these inherent instincts and reflexes as the preliminary foundation for primitive archetypes of the collective unconscious, for Freud suggests that the id is subject to permanent deposits in the personality due to the repetition of intense experiences from generation to generation. Moreover, new deposits are made during the individual's lifetime resulting from the mechanism of repression (Freud, 2003, p. 106). In Freud's Totem and taboo he argues:

Without the assumption of a mass psyche, or continuity in the emotional life of mankind which permits us to disregard the interruptions of psychic acts through the transgression of individuals, social psychology could not exist at all. If psychic processes of one generation did not continue in the next, if each had to acquire its attitude towards life afresh, there would be no progress in this field and almost no development (Freud, 1940, p. 39).

\section{Conditionality and freedom}

Freud maintains that certain psychic dispositions are inherited (Freud, 1940, p. 39) ${ }^{\mathrm{z}}$. This possibility poses obvious threats to mental freedom, implying an inability to be free of the effects of conditionality, whereby the past creates the interpretive filters through which one sees the world. Although Freud claims that an individual possesses a mental apparatus that allows him to interpret the reactions of others, this is sometimes distorted, whereby an individual pressures themselves to the point of over-morality and self-condemnation (Freud, 1940, p. 210). In such cases a tendency towards self-punishment is initiated by mere impulses: temptations one has only felt and not acted on (Freud, 1940, p. 212). This issue, the influence of the past, is something both the id and the superego have in common (Freud, 1940, p. 212). Within the context of this paper, this commonality relates to two of the greatest influences on freedom: conscience and desire.

The id is the world of subjective reality in which the pursuit of pleasure and the avoidance of pain are the only things that count (Freud, 2003, p. 100). Following this premise, when one acts impulsively one is, in fact, being dominated by the id. Freud argues:

In popular language, we may say that the ego stands for reason and circumspection, while the id stands for the untamed passions (Freud, 2008). 
By Freud's analysis of the human condition, particularly in relation to the id, psychological freedom is problematic. Moreover, any attempt to ascertain if mental freedom is possible, requires a discussion of the formation of the ego. Freud writes:

I have evolved the notion of a coherent organization of the psychic processes present within each individual and I call this organization their ego (Freud, 2003, p. 108).

Where the id certainly accentuates desire it does nothing practical to gain the desired object. It works on creating a demand and fulfilling that demand with a substitute-a memory image. Yet the individual must learn to survive in the world, to negotiate life and find an on-going way to discharge tension and reduce the anxiety caused by tension. Existence, itself, dictates the need for a degree of compromise, a compromise between the individual and the world-between intentionality and extensionality-and it is this need for compromise that necessitates a new formation in the psychological system, thus the development of the ego as the mediator. The ego is described by Freud as 'the arbiter that controls all the psyche's constituent processes' (Freud, 2003, p. 108). Freud states:

I have come to appreciate that the ego is particularly subject to the influence of perception, and that in broad terms one can say that perceptions have the same significance for the ego that drives have for the id. At the same time, however, the ego is also susceptible to the influence of drives, just like the id - of which, of course, it is but part, albeit a specially modified one (Freud, 2003, p. 130).

According to Freud, in the case of a well-adjusted person the ego is the controlling element of the personality. In other words, the ego drives the id and to some extent the superego, nonetheless Freud maintains that 'the ego is also susceptible to the influence of drives' (Freud, 2003, p. 130). In a way, one could refer to the ego as a diplomat between the internal and external world: it maintains a positive communication line between the interests of the total personality and the personality's ability to exist in the external world in a satisfactory manner (Freud, 2003, p. 116).

Freud claims that the 'ego represents what may be called reason and calm consideration, in contrast to the id, which harbours the passions' (Freud, 2003, p. 130). One could refer to the ego as the 'executive' of the personality (Hall, 1979, p. 28). Harmony and adjustment are evident when the ego is performing its executive functions well (Freud, 2003, p. 116). The ego develops out of the id and is governed by what is called the reality principle (Freud, 2003, p. 75). The reality principle relates to what actually exists, and it aims to postpone the discharge of energy or tension by creating a plan that enables a viable answer for the problem at hand. Without the reality principle, order would not be possible. It is the reality principle that stops one from eating inedible objects when one is starving: it postpones eating until something eatable is found. Clearly, the ego is the more discerning part of the personality. Freud writes:

There is no doubt...that displacement of the pleasure principle by the reality principle can be held responsible for only a very few experiences of unpleasure, and for none whatever of the most intense ones (Freud, 2003, p. 48).

From a Yogic perspective theorists often relate the word "ego" to narcissism or selfabsorption rather than mediation, linking it to asmitā: the individualised associations of 
one's consciousness (Chapple, 2008, p.6 \& Feuerstein, 1998, p. 321). Such theorists are referring to the popular definition of the word "ego", not Freudian analysis. Likewise, their definition of reality, i.e. Yoga's Reality, is distinct from Freud's. To Freud, narcissistic tendencies have to do with 'self-preservation drives' (Freud, 2003, p. 91) ${ }^{\text {aa }}$. The ego is a rational faculty, since it discriminates and therefore is more concerned with practicalities (Freud, 2003, p. 116). Freud claims:

The ego endeavours to bring the influence exerted by the external world fully to bear on the id and its designs, and makes every effort to substitute the reality principle for the pleasure principle that reigns supreme within the id' (Freud, 2003, p. 116).

In essence, if the reality principle or the ego is in power it means that there has been a suspension of the demands of the id in the interest of reality (Freud, 1995, p. 301-302). The reality principle does not set out to depose the pleasure principle but instead, to safeguard it (Freud, 1995, p. 301-302). Freud argues that the primary process creates a desire or picture of the object of need, whereas the function of the ego introduces a secondary process which realistically creates a plan to acquire the object of satisfaction (Freud, 1995, p. 301-302). The secondary process is a problem solving state, the process whereby one can plan how to get what one wants. It is able to separate the subjective nature of the desire from the object, or from the objective world (physical reality).

In Freud along the Ganges, psychoanalyst Salmon Akhtar writes:

The conscious aspect of the ego is the "executive organ" of the psyche, responsible for the integration of perceptual data and decision making. The unconscious aspect of the ego contains mechanisms, such as repression, which are necessary to counteract the powerful drives of the id (Akhtar, 2005, p. 361).

It seems plausible that the successful development of the secondary process results in a more discerning, aware and effective individual, by providing a way to master impulse. Freud's theories suggest that one has certain potentialities for reasoning and thinking that are inherent or inborn. Individuals are actually able to realise these potentialities through a process of maturation: experience, education and training. Education, if based on truth and reason, helps one to be an effective thinker (Akhtar, 2005, p. 361). Hence, to be able to think effectively means that one is able to recognise the truth (Akhtar, 2005, p. 361) ${ }^{\text {ab }}$. Therefore, when looking for a link between mental freedom and Freud's theories it is most likely found in the premise of the ego state: in one's ability to recognise the truth: one's capacity to see what could be called objective reality rather than subjective reality. Nevertheless to establish some kind of objective reality, common sense indicates a need for freedom from the constraints of guilt, or at least some kind of reconciliation regarding the reason for one's guilt. Thus this investigation comes to the next step in Freud's theory, the superego.

\section{The superego-an attachment of origin}

The superego's differentiation from the ego was by no means a chance event: it reflects the most significant developmental features of both the individual and the species; indeed, by giving lasting expression to the influence of the parents, it perpetuates the existence of the factors to which it owes its origins (Freud, 2003, p. 125). 
Freud's third system of the personality, the superego, is the realm where moral judgements are made (Freud, 2003, p. 124). Therefore, one could refer to the superego as the home for a person's moral code. The superego develops from the ego and is a result of the child's assimilation of parental directives and judgements. It evolves from one's interpretation of what one's parents believe to be good or bad, the standards or principles they demonstrated. According to Freud, 'religion, morality and a social sense' are 'acquired phylogenetically' (Freud, 2003, p. 127). In other words, one's principles and values are a part of one's psychic evolution and filter one's view of the world. This is significant when analysing the possibility of freedom, for it calls to question the ability to perceive objectively given that the foundations of one's psyche are created experientially-the child within is always present.

In most cases, a child is under parental guidance or supervision for quite some time. As the personality develops a child begins to replace the parental authority of the external world with their own internal authority and it is this process that creates the superego (Freud, 2003, pp. 124-143). The superego has two aspects called the ego-ideal and the conscience (Freud, 2003, pp. 124-143). The development of the superego is also affected by the pleasure principle because the child seeks to create pleasure by developing an internal gauge that supports the approval of their parental influence (Freud, 2003, pp. 124-143). This internal gauge allows the child to avoid the displeasure of the parents albeit the internal representation of the parents. The ego-ideal reflects the virtues of the parents (Freud, 2003, pp. 124-143). What the child adopts through the ego-ideal corresponds with what the parents consider to be morally good (Freud, 2003, pp. 124-143). For instance, if the child is rewarded in some way, the reward gained by the child becomes an ego-ideal (Freud, 2003, pp. 124-143).

In contrast, the conscience aspect of the superego relates more to the disapproval of the parents-what is considered morally bad: whatever experiences result in punishment. Thus if a child was punished for a particular act, they would then consider that act to be morally bad. Naturally this may cause disturbing behaviour when the child is punished for something that is not usually or reasonably thought of as morally bad. For instance, if the child was severely punished for just holding hands with another child then, in the extreme, he may come to view all physical contact as morally bad. Freud explains it this way:

The normal, conscious, type of guilt feeling (conscience) is easily understood: it has its basis in the tension between the ego and the ego-ideal; it is the manifestation of the fact that the ego has been condemned in some particular respect by the critical entity within it. The feelings of inferiority that are so familiar in neurotics are probably not very far removed from this (Freud, 2003, p. 140).

When it comes to the formation of the child's superego, there are two kinds of reward and punishment, psychological or physical. In respect to the psychological, this may relate to withholding approval or in the child's mind the withdrawal of love. For example, one may point to the disapproval of the parent, or the emotional rejection of the child by the parent through words or facial expressions (Freud, 2003, pp. 124-143). With regard to the physical, this may be demonstrated by an actual spanking or by taking 
away the things that the child might want (deprivation, acts of denial or aggressiveness) (Freud, 2003, pp. 124-143). Freud claims:

As each child grows up, the role of the father is taken over by teachers and other authority figures, whose commandments and prohibitions remain powerfully alive in the ego-ideal-and in due course exercise moral censorship in the guise of the conscience (Freud, 2003, p. 127).

For Freud, a person desires the approval of their parents because they believe that their parents are responsible for providing for their needs. The desire to have their parent's approval is linked to their own need to survive. This relates to the modification of the pleasure principle by the reality principle in the attainment of survival needs, such as food, shelter, warmth. Parents direct their reward or punishment by either withholding their approval or being demonstrative in their behaviour and expressing their approval (Freud, 2003, p. 127). Such punishments or rewards are situations that can either result in the reduction of tension or the increase of tension in the psychological system (Freud, 2003, p. 127).

The superego creates a system of reward and punishment upon the ego (Freud, 2003, p. 127). In a way, the superego resembles the id because it does not make a distinction between what is subjective or objective (Freud, 2003, p. 127). A thought is the same as a deed to the superego (Freud, 2003, p. 127). A person who leads a very virtuous life may still be punished by the superego just for the occasional "bad" (taboo) thought (Freud, 2003, p. 31). Freud writes:

Helplessly besieged on two fronts, the ego battles in vain against the demands of the murderous id on one hand, and the reproaches of its punitive conscience on the other (Freud, 2003, p. 143).

Freud suggests a large degree of the misfortune that one experiences in life is due to the punishing nature of the superego. This idea is linked to Freud's concept that there are no accidents, that everything that happens to a person, supposedly accidentally, is really a manifested punishment by the conscience, the superego. According to Freud, parapraxes and chance actions have this in common $^{\text {ac }}$. He claims:

The phenomena can be traced back to incompletely suppressed psychical material, which although pushed away by consciousness, has nevertheless not been robbed of all capacity for expressing itself (Freud, 1991, p. 76).

This point in itself shows a strong connection between Freud's views and Yogic philosophy; both claim that what is psychical will eventually manifest on a material level one way or another, what one believes one deserves will become reality (this is evident in the notion of karma). To Freud, even the loss of an object, misplacing something, relates to an unconscious desire for punishment. Nevertheless, although Freud relates misfortune itself to a form of self-punishment, he emphasises that the person involved is not aware of the guilt experienced by the conscience, therefore when they have an accident or some kind of misfortune it is not a deliberate act on their part. 


\section{Corruption of consciousness}

On a psychological level rewards and punishments are manifested by the superego. In the case of rewards there may be feelings of pride and esteem and in the case of punishment there may be feelings of guilt or inferiority (Freud, 2003, pp. 124-143). Freud equates pride and esteem with self-love, relating guilt and inferiority with self-hate (Freud, 2003, pp. 124-143). The way children react to other authority figures depends on what they have assimilated from their parents (Freud, 2003, pp. 124-143). With this in mind, perhaps psychological freedom relates to how one interprets the messages received and dispersed by the developing conscience, particularly in relation to punishment.

Figuratively, the conscience strives to protect one from unsociable behaviour by creating moral codes and ethical gauges. Obviously, the superego's conscience is a valuable tool for creating stability in society, restraining the individual's more primitive tendencies. However, it could also be said that the corruption of the conscience is at the root of conditionality, this leads to the development of the klessas, which eventually has a destructive influence on the individual and on the society in which they live. The selfimposed punishment one instigates towards oneself for breaching moral boundaries comes from a system of internalised arbitration borne ultimately borne from environmental issues or taboos. In other words, one's interpretation of evil may result in a corrupted psyche. Freud claims that a sense of guilt is 'the most important problem in the development of civilization'. He writes:

I often speak of a 'consciousness of guilt' instead of a 'sense of guilt'... the sense of guilt forces itself stridently on the consciousness, dominating both the clinical picture and the patient's life, and allowing hardly anything else to appear beside it ...I speak of an unconscious need for punishment, in which the sense of guilt expresses itself (Freud, 2002, p. 72).

In short, the conscience has the power to manifest a form of unconscious, guiltinduced punishment, and from a Yogic perspective, this may lead to a state of conditionality or emotional bondage. The psychic energy used in the expression of an emotion, such as aggression, is dispersed from the id and appears in the superego in the form of guilt (Freud, 2002, p. 72). Freud claims that how a person relates to others and how this relationship is reciprocated is crucial to one's development (Freud, 2002, p. 72). He argues that in infancy human beings are fully dependent on others to satisfy their needs, and that this desire for satisfaction initially drives one to learn to communicate with others, providing a way of impressing one's needs upon others (Freud, 1991, Pp. 246-248).

\section{The need to be all important}

Freud's Oedipus complex arises out of the infant's desire to be everything, be all important, to their care-giver (Freud, 1991, p. 72). But unfortunately the guilt associated with this desire, a desire which the infant learns to consider illicit or immoral, can create conflict between the ego and the libido. It is this sense of guilt that causes conflict between a child's sense of morality and their wishes (Freud, 1991, p. 72). Faced with this guilt the child then buries these supposedly "sinful" thoughts in their unconscious 
(Freud, 1991, p. 72). To Freud what is 'unconscious in mental life is also what is infantile' (Freud, 1991, p. 72) ${ }^{\text {ad }}$.

Freud substantiates his claims by emphasising the fact that human beings adopt their individual sense of morality from society's influence (Freud, 1991, p. 72). As one grows up the 'superego' or parent ego directs one to act within the boundaries of morality set up by individual beliefs. Freud argues that:

There can be no doubt that the Oedipus complex may be looked upon as one of the most important sources of the sense of guilt by which neurotics are so often tormented (Freud, 1991, p. 72).

To be free of what is infantile requires a level of awareness that is difficult to attain. In many respects we remain confined to the nature of our own limited beliefs. The repression of these unsatisfied "taboo" desires causes neurosis (Freud, 1991, p. 375). Neurotic symptoms develop when the individual experiences an internal conflict between desire and conscience (Freud, 1991, p. 375). This can be related back to the "alternating" condition, that is, a kleśa with the tendency for two opposing forces: attraction and repulsion (Taimni, 1979, p. 139).

Social survival requires the regulation of our impulses. But in many ways the corruption of the conscience (superego) is responsible for the extent of an individual's antisocial behaviour. For instance, when a distorted sense of guilt is manifested from the conscience state, such as the case where the child is punished for holding hands with another child, the child may grow up to think of themselves or their actions as evil. They may be physically or emotionally impotent, or, alternatively, they may try to achieve physical contact in any way possible (even violently) because of the internal conflict imposed by the distorted belief of the conscience. Freud's analysis of the human personality demonstrates how hard it is to experience a sense of freedom when the unconscious mind is poised to punish. From a Yogic perspective the idea of liberation is closely aligned with using meditative practice to transcend such punitive psychical $\operatorname{processes}^{\mathrm{ae}}$.

The id, the ego and the superego are interactive components of the total personality, with different processes or functions designated to each system (Freud, 1991, p. 375). This hermeneutical approach suggests that in a healthy or well-adjusted individual, the personality is integrated as a whole and is not absorbed by one process (Akhtar, 2005, p. 363). Yogic philosophies also tend to advocate an integrative process of wellbeing: an integration of the mind, body and spirit.

Philosopher and theologist Padmasiri de Silva argues in Buddhist and Freudian psychology that Freud's work and the Päli texts of early Buddhism, demonstrate a spirit of humanism (De Silva, 1992, p. 1). De Silva claims that the Buddha and Freud both understood the cause of human suffering. Although the terminology used by these two theorists is vastly different, the humanistic characteristics of their philosophies are deeply evident: they offer a prescription for 'what ails us' (De Silva, 1992, p. 1). However, Akhtar argues that Freud's notion of self 'eschews any form of spiritual transcendentalism', that Freud's prescription is more practical and less spiritual (Akhtar, 2005, p. 363). 


\section{Mastering thought}

In Yoga, meditation and the Guru, Indologist, philosopher and theologist Dr Purushottama Bilimoria describes the Hindu cosmology of spirit and matter using the following analogies:

The scintillating effect of a coloured light falling on a crystal...the photosynthetic effect of the sun's rays on a leaf...the union between a man and a woman (Bilimoria, 1989, p. 22).

One might use this analogy for the relationship between the mind and one's thoughts. The union between spirit and matter becomes manifests through the nature of thought. Mind and thought cannot be separated. Brain, on the other hand, is merely the vehicle of the mind. But where there is mind, there is always thought. From an Eastern perspective, unconscious thought is bridled or unfetter by consciousness. For Freud 'consciousness [is] the outer surface of the psychic apparatus' (Freud, 2003, p. 110). Hence, one could suggest that how free the individual becomes largely depends on the clarity of the mental processes: on their level of consciousness.

Buddhism highlights one's ability to 'control the forces at work within': that is, the ability of a person to control the dynamic forces of the past and present and make the future different from what it would otherwise be (De Silva, 1992, p. 3) ${ }^{\text {af }}$. The law of dependent origination claims that every event is conditioned by the circumstances from which it arises-everything that happens depends on something else.

Buddhism suggests that through meditation the individual (the practitioner) can become the 'master of his own fate', a concept that mirrors apperception, for to master one's own fate one must first master one's thoughts (De Silva, 1992, p. 3). De Silva claims that Freud's therapy parallels Buddhism in that it is based on the assumption that man can acquire the means to cope with his problems rationally' (De Silva, 1992, p. 3). The Buddha taught that the 'psychological and even the social conflicts of man are expressions of the in-built features of the human predicament' (De Silva, 1992, p. 171). Furthermore, the idea of duhkha (suffering) indicates that 'such conflicts and anxieties are universal, and found in everyone in different degrees' (De Silva, 1992, p. 171).

According to Freud, what one senses and feels is consciousness: 'the surface of perception' (Freud, 2003, p. 110). Yoga aspires to create a resonance between feeling and thought: a union that creates the "reins" of restraint by directing the mind: paradoxically, this control leads to freedom. This is something Yoga refers to as: citta-vrtti-nirodhahrestraint of the modifications of the mind (Feuerstein, 1989, p. 26).

When the rider takes the reins the horse becomes restrained. In other words, the mind needs to be trained: free from the destructive influences of what lies dormant. Many aspects of Eastern and Western philosophy suggest that the human predicament is centred on the conflict between pleasure and pain. Human history demonstrates the struggle between individual needs and the needs of the collective. Buddha claims this struggle is won by 'the middle way': finding the balance between the material and the spiritual, which is centred on the ultimate goal: to end suffering (Fenner, 1995, pp. 33-35). Freud's theories focus on human suffering. In 'Freud, civilization, religion and Stoicism', Douglas Kirsner writes.

Freud has a tragic view of civilization. On the one hand, much individual and social neurosis and misery derives from the creation of civilization, which requires 
renunciation of so many of our fundamental drives. The normal civilized person is neurotic-Freud's psychoanalysis is therefore politics. On the other hand, primitive life without civilization would be, as Hobbes put it, nasty, brutish, and short, even though many of our basic drives would not need to be repressed. In Stoic fashion Freud wanted to deconstruct illusion and live in reality (Kirsner, 2006, pp. 354-366).

As Kirsner points out, for Freud, society is destined to be psychically imprisoned by the traces of its cultural childhood (Kirsner, 2006, pp. 354-366). Kirsner quotes Freud's famous argument during World War I:

Our mortification and our painful disillusionment on account of the uncivilized behavior of our fellow citizens of the world...were unjustified. They were based on an illusion...In reality our fellow-citizens have not sunk so low as we feared because they had never risen so high as we believed (Kirsner, 2006, pp. 354-366).

Yoga claims: 'as the mind, so is the man' (Satchị̣ananda, 1997, p. 5). This concept suggests that one's thoughts create the individual, binding them to a pattern of thought that limits freedom or empower them beyond conditionality. It proposes that thoughts create the individual, and that these thoughts can become governed by unhelpful, fearladen and conflicted ideas. Freud's philosophy of life recognises the inner battle of the human mind. His outlook is bleak when it comes to freedom-suggesting that an individual is almost powerless against the pull of the drives. In contrast, Yoga suggests that transformation is possible. Yet Freud would most likely view this transformation as 'sublimation': he states thus: 'we can perform valued tasks such as artistic creation and intellectual inquiry-the subservience of the pleasure principle to the demands of reality' (Kirsner, 2006, pp. 354-366). Kirsner writes:

[Freud's] much criticized concept of sublimation is to do with the giving up of pleasure for long-term benefits (Kirsner, 2006, pp. 354-366).

Freud proposes that 'our mutual hostility constantly threatens our civilization with disintegration' (Kirsner, 2006, pp. 354-366). Yoga's kleśas are the driving forces of ignorance, self-centredness, addiction, hatred and fear: emotional reactions to life that inevitably influence one's interactions with others. Kleśas produce latent tendencies and, just as in a seed, germinating thoughts (vrttis) become perpetual (Balslev, 1991, pp. 77-78): leading to conditionality.

Freud suggests that the desire for survival and a need for protection is something inherent in being human. As Kirsner notes, Freud's notion of the death drive 'vitiates the possibility of a harmonious cultured human unity', emphasising that the 'history of civilization is the struggle between Eros and Thanatos, between the life and death drives' (Kirsner, 2006, pp. 354-366). One could use Yoga's concept of the Guru as a metaphor for Freud's death and life drives respectively: the dark and the light (the light is the destroyer of darkness) (Feuerstein, 1997, p. 112). One could equate Thanatos to the darkness of duhkha (suffering); suggesting that kaivalya or mokșa (liberation or release) reflect the light of Eros: life ${ }^{\text {ag }}$. 
Chapple explains in Yoga and the luminous that 'themes of light and luminosity pervade' the Yoga-Sütras (Chapple, 2008, p. 71), proposing the 'shining forth' of 'witness consciousness' (Chapple, 2008, p. 72), which he admits is generally associated with the cessation of active engagement in the world (Chapple, 2008, p. 72). Such lightness is a far cry from civilisation's current reality. One could argue that because of technological advancement, many of us are more engaged in the world than ever before, yet critics might argue that technology has also served to alienate the individual from a deeper understanding of the self, and ironically "disconnecting" us physically and emotionally from each other.

Kirsner notes that for Freud, civilization is, at best, a compromise-frustration is a side-effect of this compromise: frustration, according to Freud, that develops from suppressing sexual instincts and internalising one's tendencies towards aggression as guilt (superego) (Kirsner, 2006, pp. 354-366). Kirsner proposes that Freud's theories reflect an ethical approach, similar to Stoicism, advocating that one's maturity and mental health relate to the ability to address reality and think rationally ${ }^{\text {ah }}$. The kleśas, which sow the seeds of discontent, take one away from rational thought: away from thought based on reason and understanding. Apperception is Yoga's self-applied psychotherapy: its vehicle for reason. Ultimately, this is where Freud and Yoga unite: in the belief that emotions must be guided by the mind. Practical Yoga uses meditative practices, breath control and physical poses to achieve this aim.

In a way Freud's Stoic approach, that of 'not being dominated by emotion' (Kirsner, 2006, pp. 354-366), lends itself towards the Yogic view that one can control manas (the desiring mind) through the wisdom of buddhi (the discerning mind). The Stoic mind is clear, logical and unbiased (Kirsner, 2006, pp. 354-366). Kirsner writes further of the Stoic philosophy:

Pursuing the truth was seen as a major virtue without the distraction of anguish and suffering which stood in the way of clear and sound judgment. Although detachment from the passions was prerequisite, this did not preclude suffering from being an intrinsic part of life. Nonetheless, it meant that it did not rule life (Kirsner, 2006, pp. 354-366).

There are obvious parallels between Stoicism and Yogic philosophy, in particular the Buddhist notion of suffering as something that can be overcome if the right path or action is taken ${ }^{\text {ai }}$. Kirsner writes:

Reason, logic, and values thus merged for the stoics-objectivity was central to being able to be in control of one's suffering instead of vice versa (Kirsner, 2006, pp. 354-366).

Common to all of the theories discussed in this paper is the value of reason in leading the way to freedom, although the word "reason" has slightly different meanings to each theory and freedom is not a word they would necessarily use. Reason signifies the power of thought in transforming a human being's psyche to an instrument of hope for the future. Kirsner explains thus:

[Freud] regarded "our best hope for the future" as lying in the intellect or reason being able to establish in time "a dictatorship in the mental life of man". Freud postulated the crucial role for "such a domain of reason" that it would prove "the 
strongest uniting bond among men and lead the way to further unions" (Kirsner, 2006, pp. 354-366).

Pediatrician and psychoanalyst Donald Winnicott suggests the notion of a false and true self (Akhtar, 2009, p. 93). The false self develops from the child's over adaptation to parental and environmental influences (Akhtar, 2009, p. 93). The child 'sacrifices his true self to adapt to external demands or environmental failures' (Akhtar, 2009, p. 93). Accordingly, one sees the 'tragedy of the individual who cannot successfully live up to his parents' expectations, respond to teacher's demands, or do what his friends expect him to do' (Akhtar, 2009, p. 93). Referring to the Japanese term 'tsukuri-warai' which means 'a staged or a forced smile', Akhtar proposes that 'the secrets of the heart are handled as an event that took place in the "backstage" of life', where true feelings are hidden (Akhtar, 2009, p. 93).

It would seem that for mental freedom, or control, to be attained what is hidden must be released, revealed or resolved in some way: the individual must find their true self by letting go of the pull of the kleșas. Yoga claims that by observing and directing one's own thoughts, unhelpful emotions can be restrained. The theories discussed in this paper suggest that control of the mental processes, and an understanding of the mental system, is an important element of mental freedom. Ultimately, by taking hold of the reins, through Yoga's physical or meditative processes, or by employing therapeutic or psychoanalytic techniques, the rider may take control and perhaps learn to live unencumbered by unhelpful or unresolved emotions. The rider can thereby harness the reins of conditionality and hopefully, lead the horse in the direction of freedom.

\section{Endnotes}

${ }^{\text {a }}$ The secondary process of the organisation of the personality.

${ }^{b}$ The primary process of the organisation of the personality.

${ }^{\mathrm{c}}$ Attachment could also be described as addiction.

${ }^{\mathrm{d}}$ My paper concentrates on Classical Yoga's concept of the klesias, not on the Buddhist interpretation.

'Taimni's insights are largely inspired by the commentary of Vyāsa (sometimes referred to as Veda Vyāsa). Vyāsa is said to have compiled the four Vedas, the Mahäbhārata, together with the Bhagavad Gitā and the vast Purana literature along with other works.

f I do not intend to provide a comprehensive explanation of Sigmund Freud's theories.

${ }^{\mathrm{g}}$ The word neurosis comes from the Greek word neuron, a nerve, indicating a process or state, that is, a nervous state-a mental disorder with predominately distressing symptoms without apparent organic aetiology. S Freud, The unconscious, trans. G Frankland, Penguin Books, London, 1978, p. 3. 'The neurotic turns away from reality because he finds either the whole or parts of it unbearable'.

${ }^{\mathrm{h}} \mathrm{A}$ drive might accordingly be seen as a powerful tendency inherent in every living organism to restore a prior state, which prior state the organism was compelled to relinquish due to the disruptive influence of external forces (Freud, 2003, p. 76).

'The term "energy-cathexis" refers to the libido's charge of energy.

'Again, Taimni's insights echo the commentary of Vyāsa.

kThe Buddha's theories developed from the Hindu culture heavily influenced by Yoga. 
${ }^{\mathrm{l}}$ The id is the primary process of the psyche. The goal of the primary process is to create a discharge of energy (quantities of excitation/or tension). This energy is released into the organism through stimulation caused by either internal or external means.

${ }^{\mathrm{m}}$ This need for compromise necessitates a new formation in the psychological systemthe development of the ego as the mediator.

${ }^{\mathrm{n}}$ Freud's third system of the personality, the superego, is the realm where moral judgements are made.

${ }^{\circ}$ Freud's theory of the personality could be loosely related to asmitā, Yoga's I-sense, Taimni describes asmitā as an 'association of consciousness' conditioned by 'intervening vehicles which form a bridge between it [consciousness] and the physical body' (Taimni, 1979, p. 144).

${ }^{\mathrm{P}}$ This notion of an innate energy source is something Yoga would link to prāṇa -a vital life-force commonly associated with the breath (Feuerstein, 1998, p. 179).

${ }^{\mathrm{q}}$ In Yogic terms this is referred to as samskäras (subliminal activators or nonconscious impressions) (Feuerstein, 1997, p. 258).

'The 'discharge of quantities of excitation of energy or tension' is also the goal of Hatha Yoga practice.

${ }^{\mathrm{s}}$ Homeostasis - a medical term used to describe the body's state of well-being or balance; where all the bodily functions are working in harmony.

${ }^{t}$ From the Greek: homeo, meaning unchanging, and stasis meaning standing.

"This theory can also be related back to Jung's male and female aspects of the psyche and Yoga's iḍ̄a and pingalā.

${ }^{v}$ Memory imprint is known as subliminal activators because they motivate action.

${ }^{\mathrm{w}}$ The dream-state also relates to meditation processes and the tension reduced in the dream state is also reduced by meditation.

${ }^{\mathrm{x}}$ This is explains why lack of sleep can become a serious issue for one's well-being.

${ }^{\mathrm{y}}$ Collective unconscious' is a term used by Jung to describe an archetypal connection between all human beings on an unconscious level.

${ }^{z}$ This concept is explored thoroughly in my own work: 'Emotional genetics: habitual emotional tendencies, well-being and Yoga therapy', Australian Institute of Yoga Therapy and CAE, Melbourne, 2008.

${ }^{a a}$ Often to society's detriment altruism is overshadowed by the desire for power.

${ }^{a b}$ Freud defines the truth as 'that which exists' purporting science as a reference for the truth.

ac'Parapraxes' is a term Freud uses for errors, slips of the tongue, forgetting, bungled actions, mishearing, slips of the pen, or mislaying.

${ }^{\mathrm{ad}}$ Given the focus of this research there is limited space for in-depth discussion of the Oedipus complex. In basic terms, this theory presents the idea that every individual is subject to the remnants of their sexual development as reflected by a placement of sexual objectification on the parent of the opposite sex (named after Sophocles' story of Oedipus).

${ }^{\mathrm{ae}}$ Again, spirituality is at the heart of this Yogic journey but I am not addressing this within the context of this paper.

${ }^{\mathrm{af}}$ This represents the opposite of conditionality.

${ }^{\mathrm{ag}}$ In Yogic terms this notion of life is more than existing, it is living as one is meant to live: in the light (illuminated by awareness). 


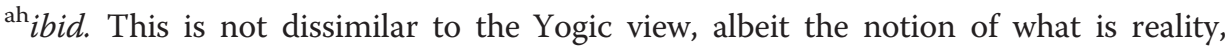
which would be fuel for debate.

ai Buddhism's Eight-fold Path is:- 1) right view, 2) right intention or thought, 3) right speech, 4) right action, 5) right livelihood, 6) right effort, 7) right concentration samādhi and 8) right mindfulness.

\section{Competing interests}

The authors declare that they have no competing interests.

\section{Authors' contributions}

JW is the sole author of this paper. The paper is adapted from her PhD dissertation (Deakin University 2013) which included empirical studies carried out by the author. JW participated in the drafting and alignment processes. All authors read and approved the final manuscript.

Received: 29 June 2014 Accepted: 26 August 2014

Published online: 30 September 2014

\section{References}

Akhtar, S. 2005. Freud Along the Ganges: Psychoanalytic Reflections on the People and Culture of India. New York: Other Press. 2005

Akhtar, S. 2009. Freud and the Far East. Landam, Maryland: Jason Aronson.

Balslev, A. 1991. The notion of kleșa and its bearing on the Yoga analysis of mind. Philosophy east and west 41(1): 77-88. Bilimoria, P. 1989. Yoga, Meditation and the Guru. Briar Hills: Indra Publishing.

Blashki, L. 2007. Graduate Certificate in Yoga Therapy: Study Guide. Melbourne: Australian Institute of Yoga Therapy and CAE.

Chapple, CK. 2008. Yoga and the Luminous: Patañjali Spiritual Path to Freedom. Albany: State University of New York Press.

Colman, AM. 2001. Dictionary of Psychology. New York: Oxford University Press.

De Silva, P. 1992. Buddhist and Freudian Psychology. Cambridge: Singapore University Press.

Fenner, P. 1987. Cognitive theories of emotions in Buddhism and western psychology'. Psychologia 30: $217-227$.

Fenner, P. 1995. Reasoning to Reality: A System-Cybernetics Model and Therapeutic Interpretation of Buddhist Middle Path Analysis. Boston: Wisdom Publications.

Feuerstein, G. 1989. The Yoga-Sūtraof Patañjali. Vermont: Inner Traditions.

Feuerstein, G. 1997. The Shambhala Encyclopaedia of Yoga. Massachusetts: Shambhala Publications Inc

Feuerstein, G. 1998. The Yoga Tradition. Arizona: Hohm Press.

Freud, S. 1940. Totem and Taboo, trans. AA Brill. Harmondsworth: Penguin Books.

Freud, S. 1975. The Future of An Illusion, trans. J Strachey. New York: WW Norton and Company.

Freud, S. 1978a. The Psychopathology of Everyday Life. London: trans, A Tyson, Penguin Books.

Freud, S. 1991. Introductory Lectures on Psychoanalysis, trans J Strachey. London: Penguin Books.

Freud, S. 1995. Formulations on the Two Principles of Mental Functioning. In Freud Reader, ed. P Gay. New York: WW Norton and Company.

Freud, S. 1999. The Interpretation of Dreams, trans Joyce Crick. New York: Oxford Press.

Freud, S. 2002. Civilization and Its Discontents, trans D McKintock. London: Penguin Books.

Freud, S. 2003. Beyond the Pleasure Principle and Other Writings, trans J Reddick. London: Penguin Books.

Freud, S, and J Breuer. 2004. Studies on hysteria, trans. N Luckhurst. London: Penguin Books.

Freud, S. 2008. The anatomy of the mental personality'. New introductory lectures on psycho-analysis 1933: retrieved 17 January 2008, www.marxists.org.

Keen, S, and A Valley-Fox. 1989. Your Mythic Journey. Los Angeles: Jeremy P Tarcher Inc.

Kirsner, D. 2006. Freud, civilization, religion, and stoicism. Psychoanalytic psychology 23(2): 354-366.

Hall, C. 1979. A Primer of Freudian Psychology. New York: Penguin Books.

Jung, CG. 1961. Memories, Dreams, and Reflections. Collins Fount: Paperbacks.

McEvoy, JP, and O Zarate. 2006. In Introducing Quantum Theory, ed. R Appignanesi. Cambridge: Icon Book.

Satchiḍānanda, Sri Swami. 1997. The Yoga Sūtras of Patañjali. Integral Yoga: Publications.

Stevenson, DB. 2003. The Libido, or Psychic Energy, in Freud. Brown: University.

Taimni, IK. 1979. The science of Yoga, 147. India: The Theosophical Publishing House.

Tortora, GJ, and B Derrickson. 2006. Principles of Anatomy and Physiology. Danvers, Massachusetts: John Wiley and Sons Ltd.

Vaillant, GE. 1995. The Wisdom of the Ego. Cambridge: Harvard University Press.

doi:10.1186/s40613-014-0007-8

Cite this article as: Wiesner: Mental freedom: Who has control-the rider or the horse?. International Journal of

Dharma Studies 2014 2:7. 